\title{
PERAN KEWIRAUSAHAAN DALAM PERTUMBUHAN EKONOMI ISLAM DI INDONESIA
}

\author{
Zakiyah Darojah \\ UIN Sunan Ampel Surabaya \\ zazkiyah.mee@gmail.com
}

M. Didanul Quro'i

UIN Sunan Ampel Surabaya

zazkiyah.mee@gmail.com

\section{Dita Kartika Dewi \\ UIN Sunan Ampel Surabaya \\ zazkiyah.mee@gmail.com}

\begin{abstract}
In economic activities, Islam encourages its people to be entrepreneurial, as taught in the Qur'an and hadith. In entrepreneurship, a person must have noble qualities, and it is forbidden to do entrepreneurship in a dishonest and unkind way. To become a successful entrepreneur, one should have a proactive, productive, empowering, hands-on (like to give) nature, humble, creative, and innovative. Entrepreneurship has become a concern of the government, especially Small and Medium Enterprises (SMEs), reducing the number of unemployment and poverty in Indonesia. Entrepreneurship has its role in Indonesia's economic growth, namely increasing productivity. Entrepreneurship also affects the development of the Islamic economy in Indonesia. That can develop sharia financial services, which include sharia banking, sharia cooperatives, sharia insurance, sharia mutual funds, etc., proves that entrepreneurship has a positive role in the growth of the Islamic economy in Indonesia.
\end{abstract}

Keywords: Entrepreneurship, Islamic economics, Indonesia.

Abstrak: Dalam kegiatan ekonomi, Islam menganjurkan umatnya agar semangat berwirausaha, sebagaimana yang diajarkan di dalam Al-Qur'an dan hadis. Dalam berwirausaha seseorang harus memiliki sifat-sifat yang mulia dan dilarang berwirausaha dengan cara yang tidak jujur dan tidak baik. Untuk menjadi seorang wirausahawan yang sukses hendaknya seseorang memiliki sifat proaktif, produktif, pemberdaya, tangan di atas (suka memberi), rendah hati, kreatif, dan inovatif. Kewirausahaan telah menjadi perhatian pemerintah khususnya Usaha Kecil Menengah (UKM). Hal tersebut dilakukan sebagai upaya mengurangi jumlah pengangguran dan kemiskinan di Indonesia. Kewirausahaan memiliki peran tersendiri dalam pertumbuhan ekonomi Indonesia yaitu peningkatan produktivitas. Kewirausahan juga mempengaruhi perkembangan ekonomi Islam di Indonesia. Hal tersebut terlihat dari perkembangan jasa keuangan syariah yang meliputi perbankan

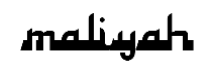

Jurnal Hukum Bisnis Islam

Volume 8, Nomor 2, Desember 2018

p-ISSN: 2088-4869/ e-ISSN: 2597-4351 
syariah, koperasi syariah, asuransi syariah, reksadana syariah, dan lain sebagainya. Hal tersebut membuktikan bahwa kewirausahaan mempunyai peran positif dalam pertumbuhan ekonomi Islam di Indonesia.

Kata Kunci: Kewirausahaan, ekonomi Islam, Indonesia.

\section{Pendahuluan}

Masalah pengangguran dan kemiskinan masih merupakan masalah besar yang dihadapi bangsa Indonesia sekarang ini dan beberapa tahun ke depan. Pada bulan September 2017, jumlah penduduk miskin (penduduk dengan pengeluaran per kapita di bawah garis kemiskinan) di Indonesia mencapai 26,58 juta orang $(10,12$ persen), berkurang sebesar 1,19 juta orang dibandingkan dengan kondisi Maret 2017 yang sebesar 27,77 juta orang $(10,64$ persen $) .{ }^{1}$ Di samping itu, angkatan kerja baru terus bertambah sekitar dua juta orang setiap tahun.

Salah satu cara mengurangi angka kemiskinan tersebut adalah dengan membangun lapangan usaha baru atau biasa disebut dengan wirausaha. Wirausaha adalah orang yang menjalankan usaha atau perusahaan dengan kemungkinan untung atau rugi. Oleh karena itu wirausaha perlu memiliki kesiapan mental, baik untuk menghadapi keadaan merugi maupun untung besar. ${ }^{2}$ Seorang wirausaha harus mempunyai karakteristik khusus yang melekat pada diri seorang wirausaha seperti percaya diri, mempunyai banyak minat, bisa bersepakat, mempunyai ambisi, berjiwa penjelajah, suka mencoba.

Saat ini, wirausaha sudah banyak macamnya, baik itu berupa usaha mikro (dalam skala kecil) maupun usaha makro

\footnotetext{
1 "Persentase Penduduk Miskin September 2017 Mencapai 10,12 Persen," Badan Pusat Statistik, September 2017, https://www.bps.go.id/pressrelease/2018/01/02/1413/persentase-pendudukmiskin-september-2017-mencapai-10-12-persen.html.

${ }^{2}$ Muhammad Yusuf Alhadihaq, "Studi Dampak Pembelajaran Program Literasi Orang Dewasa Dalam Membentuk Perilaku Berwirausaha (Studi Pada Kelompok Belajar Usaha Konveksi Di PKBM Muthia Harapan Mandiri Kecamatan Cicalengka Kabupaten Bandung)," Damar Jayagiri 1, no. VII (n.d.): 46, https://jurnal.pauddikmasjabar.my.id/index.php/damar/article/view/11.
}

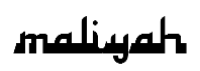

Jurnal Hukum Bisnis Islam

Volume 8, Nomor 2, Desember 2018 p-ISSN: 2088-4869/ e-ISSN: 2597-4351 
(dalam skala besar). Tidak sedikit dari mereka yang berhasil mendirikan dan mengembangkan usahanya, tetapi tidak sediki pula yang gagal. Kedua hal tersebut dapat terjadi karena kemampuan dan perilaku seseorang dalam menjalankan usaha, yang tentunya banyak tantangan dan resiko yang dihadapi.

Kewirausahaan sendiri telah menjadi perhatian pemerintah khususnya Usaha Kecil Menengah (UKM). ${ }^{3}$ Perhatian pemerintah tersebut telah menjadi proyek tersendiri bagi pemerintah khususnya dalam mengurangi jumlah pengangguran yang kian bertambah. Proyek tersebut dijalankan dengan cara memberikan pinjaman pembiayaan usaha yang terdapat pada Dinas Koperasi, sehingga dapat memudahkan masyarakat yang tidak memiliki modal dalam mendirikan suatu usaha. Selain berperan dalam aspek tenaga kerja, kewirausahaan memiliki peran tersendiri dalam pertumbuhan ekonomi Indonesia yaitu peningkatan produktivitas yang mengakibatkan surplus perdagangan dan menurunkan jumlah barang impor.

Usaha kecil, khususnya di sektor produksi akan menyerap tenaga kerja yang luas dan jauh lebih besar. Beberapa studi menunjukkan bahwa industri kecil dan usaha mikro memberikan kontribusi yang cukup besar dalam menciptakan lapangan pekerjaan dan memperoleh pendapatan. Hal tersebut menunjukkan secara langsung bahwa mereka mampu mengembangkan pendapatan dan memenuhi permintaan barang, jasa, peralatan, bahan baku dan ekspor.

Konsep syariah yang diterapkan di bank-bank sudah membuktikan, bagaimana penyaluran pembiayaan di bank syariah selalu berpihak pada sektor riil, dengan angka finance to deposit ratio yang relatif tinggi. Kehadiran bank syariah terbukti bisa diarahkan untuk mendorong tumbuhnya sektor riil, usaha kecil dan menengah yang selama ini menjadi

\footnotetext{
${ }^{3}$ Endang Purwanti, "Pengaruh Karakteristik Wirausaha, Modal Usaha, Strategi Pemasaran Terhadap Perkembangan Umkm Di Desa Dayaan Dan Kalilondo Salatiga," Among Makarti 5, no. 9 (2012): 13, https://jurnal.stieama.ac.id/index.php/ama/article/view/65/46.
} 
primadona dan tulang punggung di masa krisis. Tanpa keterlibatan wirausaha, sulit bagi pemerintah untuk menekan angka kemiskinan dan pengangguran, berdasarkan slogan "Entrepreneur adalah pahlawan dalam banyak hal". Berdasarkan hal di atas, maka artikel ini membahas tentang Peran Kewirausahaan dalam Pertumbuhan Ekonomi Islam di Indonesia.

\section{Konsep Dasar Kewirausahaan}

Kewirausahaan merupakan padanan kata dari entrepreneur atau ada juga yang menyebutnya wiraswasta. Secara bahasa (etimologis) wira berarti perwira, utama, teladan, berani. Swa berarti sendiri, sedangkan sta berarti berdiri. Sedangkan atri kata entrepreneur sendiri berarti petualang, pencipta, dan pengelola usaha. ${ }^{4}$

Menurut Suryana, kewirausahaan merupakan kemampuan kreatif dan inovatif yang dimiliki oleh seseorang, sehingga dijadikan dasar, kiat, dan sumber daya untuk mencari peluang menuju kesuksesan. ${ }^{5}$ Kewirausahaan merupakan proses penciptaan sesuatu dengan menggunakan waktu dan kegiatan disertai modal dan resiko serta menerima balas jasa dan kepuasan serta kebebasan pribadi. Kewirausahaan lebih merujuk pada sifat, watak, dan ciri-ciri yang melekat pada seseorang yang mempunyai kemauan keras untuk mewujudkan gagasan inovatif ke dalam dunia usaha yang nyata dan dapat mengembangkannya dengan tangguh. ${ }^{6}$

Kewirausahaan dan wirausaha merupakan faktor produksi aktif yang dapat menggerakkan dan memanfaatkan sumber daya lainnya seperti sumber daya alam, modal, dan teknologi, sehingga dapat menciptakan kekayaan dan kemakmuran malalui menciptakan lapangan kerja, penghasilan

4 M. Ma'ruf Abdullah, Wirausaha Berbasis Syariah (Banjarmasin: Antasari Press, 2011), 1.

5 Yunus Sunarya and Kartib Bayu, Kewirausahaan Pendekatan Karakteristik Wirausahawan Sukses (Jakarta: Kencana Prenada Media Group, 2010), 12.

${ }^{6}$ Ibid. 
dan produk yang diberlakukan di masyarakat. Faktor yang mempengaruhi tindakan kewirausahaan yaitu hak milik, kemampuan, dan lingkungan ekstenal. ${ }^{7}$

Kewirausahaan merupakan semangat, perilaku, dan kemampuan dalam kreatifitas dan berinovasi serta memberikan tanggapan yang positif terdapat peluang memperoleh keuntungan untuk diri sendiri dan pelayanan yang lebih baik terhadap masyarakat, dengan selalu berusaha mencari dan melayani masyarakat lebih banyak dan lebih baik, serta menciptakan dan menyediakan produk yang lebih bermanfaat dan menerapkan cara kerja yang efisien, melalui keberanian mengambil resiko, kreatifitas, dan inovasi, serta kemampuan manajemen. ${ }^{8}$

Yang menjadi dorongan berwirausaha antara lain:

1. Kebutuhan akan ketidaktergantungan atau kebebasan.

2. Kebutuhan akan pembaharuan.

3. Mencapai tingkat pendapatan yang lebih baik.

4. Kemampuan menyekolahkan anak dan mensejahterakan keluarga.

Selain itu terdapat karakteristik kewirausahaan yang harus dimiliki oleh seorang wirausaha antara lain:

1. Proaktif, yaitu suka mencari informasi yang ada hubugannya dengan dunia yang digelutinya, agar mereka tidak ketinggalan informasi, sehingga segala sesuatu dapat disikapi dengan bijak dan tepat.

2. Produktif, yaitu selalu ingin mengeluarkan untuk hal-hal yang produktif. Ia tidak sembarang mengeluarkan uang tetapi harus tetap teliti, cermat, dan penuh perhitungan dalam memutuskan pengeluaran.

3. Pemberdaya, yaitu harus bisa memahami bagaimana menangani pekerjaan dengan membagi tugas dan memberdayakan orang lain yang ada dalam pembinaannya untuk mencapai tujuan yang diinginkan.

${ }^{7}$ Ibid., 13.

${ }^{8}$ Ibid., 17 
4. Tangan di atas, seorang entrepreneur, lebih-lebih entrepreneur yang berbasis syariah umumnya mempunyai karakter tangan diatas (suka memberi).

5. Rendah hati, harus menyadari keberhasilan yang dicapainya bukan sepenuhnya karena kehebatannya, tetapi ia harus sadar betul disamping upayanya yang sungguh-sungguh ia juga tidak terlepas dari pertolongan Allah.

6. Kreatif, seorang wirausaha harus memiliki karakter kreatif, yaitu mampu menangkap dan menciptakan peluang-peluang bisnis yang bisa dikembangkan.

7. Inovatif, yaitu mampu melakukan pembaruan-pembaruan dalam menangani bisnis yang digelutinya, sehingga bisnis yang dilakukannya selalu dapat mengikuti perkembangan zaman.9

\section{Tahap-tahap dan Proses dalam Kewirausahaan}

Secara umum tahap-tahap melakukan wirausaha yaitu:

1. Tahap memulai, tahap di mana seseorang yang berniat untuk melakukan usaha mempersiapkan segala sesuatu yang diperlukan, diawali dengan melihat peluang usaha baru, melakukan akuisisi, melakukan franchising, dan memilih jenis usaha yang akan dilakukan apakah di bidang pertanian, industri, manufaktur, produksi atau jasa.

2. Tahap melaksanakan usaha atau tahap jalan. Dalam tahap ini, seorang wirausahawan mengelola berbagai aspek yang terkait dengan usahanya, mencakup aspek pembiayaan, SDM, kepemilikan, organisasi, kepemimpinan yang meliputi bagaimana mengambil resiko dan mengambil keputusan, pemasaran dan melakukan evauasi.

3. Tahap mempertahan usaha. Dalam tahap ini merupakan tahap dimana wirausahawan melakukan analisis perkembangan berdasarkan hasil yang dicapai untuk ditindaklanjuti sesuai dengan kondisi yang dihadapi.

4. Tahap mengembangkan usaha. Dalam tahap ini, jika hasil yang diperoleh tergolong positif atau mengalami

\footnotetext{
${ }^{9}$ Abdullah, Wirausaha Berbasis Syariah, 3-8.
}

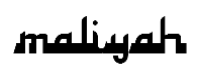

Jurnal Hukum Bisnis Islam 
perkembangan atau dapat bertahan maka perluasan usaha menjadi salah satu pilihan yang mungkin bisa diambil.

Proses kewirausahaan diawali dengan adanya inovasi. Inovasi tersebut dipengeruhi oleh berbagai faktor baik yang berasal dari pribadi maupun di luar pribadi, seperti pendidikan, sosiologi, organisasi, kebudayaan dan lingkungan. ${ }^{10}$ Faktor-faktor tersebut membentuk locus of control, kreativitas, keinovasian, implementasi, dan pertumbuhan yang kemudian berkembangan menjadi wirausaha yang besar. Secara internal, keinovasian dipengaruhi oleh faktor yang bersal dari individu, seperti locus of control, toleransi, nilai-nilai, pendidikan, dan pengalaman. Sedangkan faktor yang berasal dari lingkungan yang mempengaruhi diantaranya model peran, aktivitas, dan peluang. Oleh karena itu, inovasi berkembangan menjadi kewirausahaan melalui proses yang dipengrauhi lingkungan, organisasi dan keluarga. ${ }^{11}$

Berdasarkan analisis pustaka terkait kewirausahaan, diketahui bahwa aspek-aspek yang perlu diperhatikan dalam melakukan wirausaha adalah:

1. Mencari peluang usaha baru: lama usaha dilakukan, dan jenis usaha yang pernah dilakukan,

2. Pembiayaan: pendanaan - jumlah dan sumber-sumber dana,

3. SDM: tenaga kerja yang dipergunakan,

4. Kepemilikan: peran-peran dalam pelaksanaan usaha,

5. Organisasi: pembagian kerja diantara tenaga kerja yang dimiliki,

6. Kepemimpinan: kejujuran, agama, tujuan jangka panjang, proses manajerial (POAC),

7. Pemasaran: lokasi dan tempat usaha.

\section{Motivasi Kewirausahaan}

\footnotetext{
${ }^{10}$ Rahma Nurvidiana et al., "Proses Kewirausahaan," Makalah, 2013, 2.

${ }^{11}$ Maya Malinda, "Faktor-Faktor Yang Mempengaruhi Seseorang Berwirausaha (Sebuah Kajian Literatur)," Jurnal Manajemen Maranatha 1, no. Mei (2002): 107, https://media.neliti.com/media/publications/113583-ID-faktor-faktor-yangmempengaruhi-seseoran.pdf.
} 
Motivasi merupakan proses psikologis yang mendasar, dan merupakan salah satu unsur yang dapat menjelaskan perilaku seseorang. Motivasi merupakan salah satu faktor penentu dalam pencapaian tujuan. Motiovasi berhubungan dengan dorongan atau kekuatan yang berada pada diri manusia. Motivasi menggerakkan manusia untuk menampilkan tingkah laku ke arah pencapaian suatu tujuan tertentu. ${ }^{12}$

Motivasi untuk menjadi wirausaha biasanya muncul dengan sendirinya setelah seseorang merasa memiliki bekal yang cukup untuk mengola usaha dan juga siap mental secara total. Secara umum motivasi seseorang untuk menjadi wirausaha antara lain:

1. Laba: Dapat menentukan berapa laba yang dikehendaki, keuntungan yang diterima, dan berapa yang akan dibayarkan kepada pihak lain atau pegawainya.

2. Kebebasan: Bebas mengetur waktu, bebas dari superviser, bebas aturan main yang menekan atau inventaris orang lain, bebas dari aturan budaya organisasi atau perusahaan.

3. Impian Personal: Bebas mencapai standar hidup yang diharapkan, lepas dari rutinitas kerja yang membosankan karena harus mengikuti visi, misi, dan impian orang lain. Dapat menentukan nasib/visi, misi, dan impian sendiri.

4. Kemandirian: Memiliki rasa bangga karena dapat mandiri dalam segala hal, seperti peromodalan, mandiri dalam pengelolaan/manajemen, mandiri dalam pengawasan, serta menjadi manajer terhadap dirinya sendiri.

Dengan berwirausaha seseorang termotivasi untuk memperoleh imbalan dalam bentuk laba, kebebasan, impian personal yang mungkin terjadi kenyataan, dan kemandirian. Selain memiliki peluang untuk mengembangkan usaha juga berpeluang untuk mengendalikan nasibnya sendiri.

Terdapat beberapa cara dalam membangun motivasi wirausaha:

\footnotetext{
12 Sunarya and Bayu, Kewirausahaan Pendekatan Karakteristik Wirausahawan Sukses, 86.
}

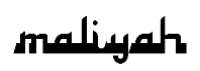

Jurnal Hukum Bisnis Islam 
1. Membulatkan tekad, yaitu seorang yang benar-benar dapat membulatkan tekad berani melangkah dan insya Allah akan berhasil, sedangkan orang yang setengah-setengah dan tidak dapat membulatkan tekadnya, tidak berani melangkah dan akan gagal.

2. Belajar dari filsafat alam, yaitu, alam yang terbentang luas dan segala isinya ini banyak yang bisa dijadikan pelajaran bagi seorang calon wirausaha.

3. Belajar dari pengalaman wirausaha yang suskes, Nabi Muhammad SAW merupakan contoh tauladan dalam kehidupan manusia, termasuk dalam hal kewirausahaan. Nabi Muhammad dalam melakoni kehidupan sebagai entrepreneur melalui empat tahapan karekter, yaitu:

a. Integrity, atau integritas yang merupakan sifat yang menjadi pondasi utama karakter seorang pengusaha yaitu kejujuran yang mengikat utuh karakter-karakter positif lainnya.

b. Loyality, atau loyalitas merupakan sifat pendukung yang menguatkan kepercayaan orang banyak. Loyalitas berhubungan dengan kesetiaan dan komitmen jangka panjang.

c. Profesionality, merupakan kapasitas untuk menjalankan suatu profesi dengan ukuran-ukuran standar serta kualitas terbaik. Nabi Muhammad SAW juga menggunakan hukum dan standar pemasaran yang saat ini dekenal dengan istilah segmentation, positioning, dan targeting.

d. Spirituality, atau spiritual, sebagai pengelola bisnis Nabi Muhammad SAW juga peduli dengan masalah-masalah akhlak sehingga Nabi Muhammad SAW adalah tokoh utama yang kemudian melahirkan konsep spiritual marketing.

4. Mengikuti program pengembangan, diantaranya: a) meningkatkan aktivitas perekonomian di masyarakat, daerah, dan Negara secara keseluruhan, b) meningkatkan income (pendapatan) orang per orang, masyarakat, daerah, 
dan Negara secara keseluruhan, dan c) menyerap tenaga kerja yang belum mendapat pekerjaan.

5. Kunjungan kerja, kunjungan kerja ke sentra-sentra kegiatan ekonomi/industri yang lebih maju sangat berpengaruh untuk memotivasi semangat wirausaha. ${ }^{13}$

\section{Keuntungan dan Kelemahan Menjadi Wirausaha}

Berbagai keuntungan menjadi wirausaha menurut Buchari Alma adalah sebagai berikut:

1. Mendapat peluang untuk mencapai tujuan yang diinginkannya.

2. Terbuka peluang untuk mendemonstrasikan potensi diri secara penuh.

3. Terbuka peluang untuk memperoleh manfaat dan keuntungan maksimal.

4. Terbuka peluang untuk membantu masyarakat dengan usaha-usaha yang kongkret.

5. Terbuka peluang untuk menjadi bos, minimal bagi dirinya sendiri. ${ }^{14}$

Selain itu, keuntungan lain dari kewirausahaan adalah:

1. Otonomi, adanya suatu kebebasan dalam mengatur waktu kerja, mengelola keuangan, menggunakan sumberdaya yang diperlukan sesuai dengan ukuran-ukuran yang kita kehendaki dan kita yakini tepat.

2. Dapat memanfaatkan peluang motif berprestasi.

3. Dapat memanfaatkan waktu-waktu luang yang ada.

4. Dapat mengatur, mendistribusikan dan memanfaatkan penggunaan keuntungan sesuai dengan kehendak dan keyakinan.

5. Dapat membantu anggota masyarakat dalam hal menyediakan barang/jasa keperluan hidup, membimbing/mendidik calon wirausaha yang ingin terjun ke dunia bisnis dan turut membuka kesempatan atau

${ }^{13}$ Sunarya and Bayu, 49-63.

14 PO Abas Sunarya, Sudaryono, and Asep Saefullah, Kewirausahaan (Yogyakarta: C.V Andi Affset, 2011), 19-20. 
lowongan pekerjaan bagi anggoota masyarakat yang belum bekerja.

6. Ada rasa kepuasan batin yang luas dan dalam yang merupakan kebahagiaan tersendiri.15

Kelemahan menjadi seorang wirausaha, yaitu:

1. Memperoleh pendapatan yang tidak pasti dan memikul berbagai resiko.

2. Harus bekerja keras dan dengan jam kerja yang mungkin lebih panjang.

3. Kualitas hidupnya mungkin masih rendah sampai usahanya berhasil. Pada tahap awal, wirausaha harus bersedia hemat.

4. Memiliki tanggung jawab sangat besar. ${ }^{16}$

\section{Kewirausahaan Berbasis Syariah}

Islam memang tidak memberikan penjelasan secara eksplisit terkait konsep tentang kewirausahaan (entrepreneurship), namun dalam Islam digunakan istilah kerja keras, kemandirian (biyadihi), dan tidak cengeng. Terdapat beberapa ayat al-Qur'an maupun Hadis yang dapat menjadi rujukan pesan tentang semangat kerja keras dan kemandirian ini, seperti; "Amal yang paling baik adalah pekerjaan yang dilakukan dengan cucuran keringatnya sendiri, 'amal ar-rajul bi yadihi (HR. Abu Dawud)".

Dalam sebuah ayat Allah mengatakan, "Bekerjalah kamu, maka Allah dan orang-orang yang beriman akan melihat pekerjaan kamu" (Q.S. at-Taubah: 105). Oleh karena itu, apabila shalat telah ditunaikan maka bertebaranlah kamu di muka bumi dan carilah karunia (rizki) Allah. (Q.S. al-Jumu'ah: 10).

Nash-nash tersebut jelas memberikan isyarat agar manusia bekerja keras dan hidup mandiri. Bekerja keras merupakan esensi dari kewirausahaan. Prinsip kerja keras, adalah suatu langkah nyata yang dapat menghasilkan kesuksesan (rezeki), tetapi harus melalui proses yang penuh

\footnotetext{
15 Abdullah, Wirausaha Berbasis Syariah, 149-50.

${ }^{16}$ Sunarya, Sudaryono, and Saefullah, Kewirausahaan.
} 
dengan tantangan (resiko). Dengan kata lain, orang yang berani melewati resiko akan memperoleh peluang rizki yang besar.

Dalam sejarahnya, Nabi Muhammad, istrinya dan sebagian besar sahabatnya adalah para pedagang dan entrepreneur mancanegara yang pawai. Beliau adalah praktisi ekonomi dan sosok tauladan bagi umat. Oleh karena itu, sebenarnya tidaklah asing jika dikatakan bahwa mental entrepreneurship inheren dengan jiwa umat Islam itu sendiri.

Dari aktivitas perdagangan yang dilakukan, Nabi dan sebagian besar sahabat telah mengubah pandangan dunia bahwa kemuliaan seseorang bukan terletak pada kebangsawanan darah, tidak pula pada jabatan yang tinggi, atau uang yang banyak, melainkan pada pekerjaan.

Oleh karena itu, Nabi juga bersabda "Inna Allah yuhib almuhtarif" (sesungguhnya Allah sangat mencintai orang yang bekerja untuk mendapatkan penghasilan). Umar Ibnu Khattab mengatakan sebaliknya bahwa, "Aku benci salah seorang di antara kalian yang tidak mau bekerja yang menyangkut urusan dunia."

Sejarah juga mencatat sejumlah tokoh Islam terkenal yang juga sebagai pengusaha tangguh, Abdul Ghani Aziz, Agus Dasaad, Djohan Soetan, Perpatih, Jhohan Soelaiman, Haji Samanhudi, Haji Syamsuddin, Niti Semito, dan Rahman Tamin.

Adapun Motif Berwirausaha menurut ajaran agama Islam, yaitu:

1. Berdagang bukan untuk Cari Untung

Pekerjaan berdagang adalah sebagian dari pekerjaan bisnis yang sebagian besar bertujuan untuk mencari laba sehingga seringkali untuk mencapainya dilakukan hal-hal yang tidak baik. Padahal ini sangat dilarang dalam agama Islam. Seperti diungkapkan dalam hadis : "Allah mengasihi orang yang bermurah hati waktu menjual, waktu membeli, dan waktu menagih piutang."

2. Berdagang adalah Hobi

Konsep berdagang adalah hobi banyak dianut oleh para pedagang dari Cina. Mereka menekuni kegiatan berdagang ini dengan sebaik-baiknya dengan melakukan berbagai 
macam terobosan.Yaitu dengan open display (melakukan pajangan di halaman terbuka untuk menarik minat orang), window display (melakukan pajangan di depan toko), interior display (pajangan yang disusun didalam toko), dan close display (pajangan khusus barang-barang berharga agar tidak dicuri oleh orang yang jahat).

3. Berdagang adalah Ibadah

Bagi umat Islam berdagang lebih kepada bentuk Ibadah kepada Allah swt. Karena apapun yang dilakukan harus memiliki niat untuk beribadah agar mendapat berkah. Berdagang dengan niat ini akan mempermudah jalan kita mendapatkan rezeki.

Berwirausaha memberi peluang kepada orang lain untuk berbuat baik dengan cara memberikan pelayanan yang cepat, membantu kemudahan bagi orang yang berbelanja, memberi potongan, dll. Perbuatan baik akan selalu menenangkan pikiran yang kemudian akan turut membantu kesehatan jasmani.

4. Perintah Kerja Keras

Kemauan yang keras dapat menggerakkan motivasi untuk bekerja dengan sungguh-sungguh. Orang akan berhasil apabila mau bekerja keras, tahan menderita, dan mampu berjuang untuk memperbaiki nasibnya. Untuk mencapai sukses dalam karir seseorang, maka harus dimulai dengan kerja keras. Kemudian diikuti dengan mencapai tujuan dengan orang lain, penampilan yang baik, keyakinan diri, membuat keputusan, pendidikan, dorongan ambisi, dan pintar berkomunikasi. Allah memerintahkan kita untuk tawakkal dan bekerja keras untuk dapat mengubah nasib. Jadi intinya adalah inisiatif, motivasi, kreatif yang akan menumbuhkan kreativitas untuk perbaikan hidup. Selain itu kita juga dianjurkan untuk tetap berdoa dan memohon perlindungan kepada Allah swt sesibuk apapun kita berusaha karena Dialah yang menentukan akhir dari setiap usaha.

5. Perdagangan/ Berwirausaha Pekerjaan Mulia Dalam Islam 
Pekerjaan berdagang ini mendapat tempat terhormat dalam ajaran Islam, seperti disabdakan Rasul:

"Mata pencarian apakah yang paling baik, Ya Rasulullah?"Jawab beliau: Ialah seseorang yang bekerja dengan tangannya sendiri dan setiap jual beli yang bersih." (HR. Al-Bazzar).

Allah swt juga telah menghalalkan kegiatan jual beli dan mengharamkan riba. Kegiatan riba ini sangat merugikan karena membuat kegiatan perdagangan tidak berkembang. Hal ini disebabkan karena uang dan modal hanya berputar pada satu pihak saja yang akhirnya dapat mengeksploitasi masyarakat yang terdesak kebutuhan hidup.

\section{Semangat Kewirausahaan Berbasis Syariah}

Semangat kewirausahaan yang perlu dimasyarakatkan dan dibudidayakan antara lain:

1. Kemauan kuat untuk berkarya (utamanya di bidang ekonomi).

2. Mampu membuat kepuasan yang tepat dan berani mengambil resiko.

3. Kreatif dan iniovatif.

4. Tekun,teliti, dan produktif.

5. Berkarya dengan semangat kebersamaan dan etika bisnis yang sehat.

Semangat-semangat dalam berwirausaha banyak ditemukan dalam ayat-ayat Al-Qur'an. Misal dalam QS. Al-Hajj: 77 yang berbunyi:

"Hai orang-orang yang beriman, ruku'lah kamu, sujudlah kamu, sembahlah Tuhanmu dan perbuatlah kebajikan, supaya kamu mendapat kemenangan."

Disini disebutkan bahwa kita disuruh berbuat baik (bekerja dengan baik dan profesional) agar kita mendapat kemenangan, bekerja selama ini sering kali dikaitkan dengan urusan dunia namun pada dasarnya bekerja setara atau sejajar dengan rukuk, bersujud, dan menyembah Allah SWT. Artinya bekerja juga merupakan ibadah.

QS Al-nahl: 97, yang berbunyi:

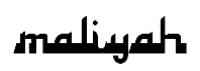

Jurnal Hukum Bisnis Islam

Volume 8, Nomor 2, Desember 2018 p-ISSN: 2088-4869/ e-ISSN: 2597-4351 
"Barangsiapa yang mengerjakan amal saleh, baik laki-laki maupun perempuan dalam Keadaan beriman, maka sesungguhnya akan Kami berikan kepadanya kehidupan yang baik, dan sesungguhnya akan Kami beri balasan kepada mereka dengan pahala yang lebih baik dari apa yang telah mereka kerjakan."

Ayat ini menjanjikan manusia bahwasanya balasan bekerja adalah kehidupan yang layak dan pahala yang baik melebihi nilai kebaikan dari pekerjaan yang dikerjakan. Disini menyiratkan bahwa bekerja itu memiliki nilai plus.

Dalam QS Aljumuah: 10, yang berbunyi:

"Apabila telah ditunaikan shalat, Maka bertebaranlah kamu di muka bumi; dan carilah karunia Allah dan ingatlah Allah banyak-banyak supaya kamu beruntung."

Dalam ayat ini dijelaskan bahwa Allah memerintahkan bekerja, Allah juga berfirman bahwa bekerja sambil mengingatNya (bekerja sesuai dengan prosedur agama Islam) akan mendatangkan keuntungan.

QS At-taubah: 105 yang berbunyi:

"Dan Katakanlah: "Bekerjalah kamu, maka Allah dan Rasul-Nya serta orang-orang mukmin akan melihat pekerjaanmu itu, dan kamu akan dikembalikan kepada (Allah) yang mengetahui akan yang ghaib dan yang nyata, lalu diberitakan-Nya kepada kamu apa yang telah kamu kerjakan."

Dalam ayat ini dijelaskan kepada semua umat bahwa bekerja itu tidak semata-mata urusan dunia. Bekerja tidak saja berimplikasi kepada dunia, tetapi juga akhirat. Kelak pekerjaan itulah yang akan dinilai oleh Allah.

Masih banyak ayat lainnya yang memberikan semangat wirausaha kepada umat Islam. Tidak hanya Al-Qur'an, hadishadis Nabi Muhammad SAW pun mengisyaratkan hal yang sama. Nabi Muhammad SAW pernah bersabda:

"Tiada makanan yang baik bagi anak Adam, kecuali yang ia dapat dari tangannya sendiri. Sesungguhnya, Nabi Daud AS makan dari hasil kreativitas tangannya (wirausaha)." (HR Bukhari). 
Nabi Muhammad SAW juga pernah bersabda:

"Hendaklah kami berdagang karena di dalamnya terdapat 90 persen pintu rezeki." (HR Ahmad bin Hanbal). Nabi juga pernah bersabda tentang hal yang sama, "Sesungguhnya, sebaik-sebaik mata pencarian adalah seorang pedagang." (HR Baihaqy).

Jadi, bekerja atau berentrepreneur dalam Islam merupakan kewajiban yang menjadi ibadah bagi pelakunya. Bahkan, bekerja atau berwirausaha menjadi salah satu ciri orang yang beriman.

Bekerja sejatinya adalah beribadah kepada Allah SWT. Karena itu, bekerja akan mendapatkan pahala, bahkan ganjaran yang tertinggi dari sebuah keimanan, yakni bertemu Allah (liqa'u rabbi). Bekerja adalah ibadah maka bekerja harus sesuai dengan syariat Allah, yakni dengan cara yang halal, baik, dan bermanfaat. Bekerja adalah ibadah maka tujuan bekerja hanyalah untuk Allah SWT, bukan untuk bekerja atau materi itu sendiri.

\section{Perilaku Terpuji Dalam Berwirausaha Berbasis Syariah}

Menurut Imam Ghazali, ada 6 sifat perilaku yang terpuji dalam perdagangan atau Berwirausaha, yaitu:

1. Tidak mengambil laba lebih banyak.

Membayar harga yang sedikit lebih mahal kepada pedagang yang miskin. Memurahkan harga dan memberi potongan kepada pembeli yang miskin sehingga akan melipatgandakan pahala. Bila membayar hutang, maka bayarlah lebih cepat dari waktu yang telah ditetapkan. Membatalkan jual beli bila pihak pembeli menginginkannya. Bila menjual bahan pangan kepada orang miskin secara cicilan, maka jangan ditagih apabila orang tersebut tidak mampu membayarnya dan membebaskan ia dari hutang apabila meninggal dunia.

2. Manajemen Utang Piutang

Dosa hutang tidak akan hilang apabila tidak dibayarkan. Bahkan orang yang mati syahidpun dosa utangnya tidak berampun. Jadi jika seseorang meninggal, maka ahli 
warisnya wajib melunasi hutang tersebut. Tapi jika orang tersebut telah berusaha membayarnya, tetapi memang betul-betul tidak mampu, dan ia kemudian meninggal dunia, maka Rasul saw menjadi penjaminnya. Seperti dalam hadis berikut:

"Barang siapa dari umatku yang punya hutang, kemudian ia berusaha keras untuk membayarnya, lalu ia meninggal dunia sebelum lunas hutangnya, maka aku sebagai walinya." (HR. Ahmad).

3. Demonstration Effect Menyebabkan Faktor Modal Menjadi Beku

Demonstration Effect atau pamer kekayaan akan dapat mengundang kecemburuan sosial, orang lain menjadi iri, mengundang pencuri/perampok, membuat modal masyarakat menjadi beku dan membuat masyarakat tidak produktif. Nabi saw menganjurkan agar kita menggunakan uang untuk kepentingan yang diridhoi Allah, terutama untuk tujuan pengembangan produktivitas yang digunakan untuk kepentingan umat. Dalam sebuah hadist disebutkan bahwa apabila kita memiliki modal, maka janganlah disimpan begitu saja, tetapi harus digunakan untuk sesuatu yang menghasilkan.

4. Membina Tenaga Kerja Bawahan

Hubungan antara pengusaha dan pekerja harus dilandasi oleh rasa kasih sayang, saling membutuhkan, dan tolong menolong. Hal ini dapat dilihat dari hubungan dalam bidang pekerjaan. Pengusaha menyediakan lapangan kerja dan pekerja menerima rezeki berupa upah dari pengusaha. Majikan mempunyai hak untuk memerintah bawahan dan mendapat keuntungan. Majikan juga memiliki kewajiban yaitu membayar upah karyawan sesegera mungkin dan melindungi karyawannya. Seperti dalam hadis berikut: 
"Berikanlah kepada karyawanmu upahnya sebelum kering keringatnya." (HR. Ibnu Majah), ${ }^{17}$

Sifat yang harus dimiliki oleh seorang wirausaha yang sesuai dengan ajaran agama Islam adalah:

1. Sifat Takwa, Tawakkal, Zikir, dan Syuku

2. Jujur

3. Niat Suci dan Ibadah

4. Azzam dan bangun Lebih Pagi

5. Toleransi

6. Berzakat dan Berinfak

7. Silaturahmi

\section{Prinsip Dasar Ekonomi Islam}

Ada tiga sistem ekonomi yang ada di muka bumi ini yaitu Kapitalis, sosialis dan Mix Economic. Sistem ekonomi tersebut merupakan sistem ekonomi yang berkembang berdasarkan pemikiran barat. Namun sistem ekonomi tersebut membawa akibat negatif dan lebih buruk, karena banyak negara miskin bertambah miskin dan negara kaya yang jumlahnya relatif sedikit semakin kaya, masing-masing sistem ekonomi mempunyai kelemahan atau kekurangan yang lebih besar dibandingkan dengan kelebihan masing-masing. Kelemahan atau kekurangan dari masing-masing sistem ekonomi tersebut lebih menonjol ketimbang kelebihannya.

Karena kelemahannya atau kekurangannya lebih menonjol daripada kebaikan menyebabkan muncul pemikiran baru tentang sistem ekonomi terutama di kalangan negaranegara muslim atau negara-negara yang mayoritas penduduknya beragama Islam yaitu sistem ekonomi Islam. Negara-negara yang penduduknya mayoritas Muslim mencoba untuk mewujudkan suatu sistem ekonomi yang didasarkan pada Al-Qur'an dan Hadis, yaitu sistem ekonomi Islam yang telah berhasil membawa umat muslim pada zaman Rasulullah

17 "Islam Dan Mental Kewirausahaan," 2009, http://insaniaku.files.wordpress.com/2009/03/4-islam-dan-mentalkewirausahaan-subur.pdf. 
meningkatkan perekonomian di Jazirah Arab, dari pemikiran yang didasarkan pada Al-Qur'an dan Hadis.

Pengembangan ekonomi Syariah dan Sistem Ekonomi Syariah bukan untuk menyaingi sistem ekonomi kapitalis atau sistem ekonomi sosialis, tetapi lebih ditujukan untuk mencari suatu sistem ekonomi yang mempunyai kelebihan-kelebihan untuk menutupi kekurangan-kekurangan dari sistem ekonomi yang telah ada. Islam diturunkan ke muka bumi ini dimaksudkan untuk mengatur hidup manusia guna mewujudkan ketentraman hidup dan kebahagiaan umat di dunia dan di akhirat sebagai nilai ekonomi tertinggi. Umat di sini tidak semata-mata umat Muslim tetapi seluruh umat yang ada di muka bumi. Ketentraman hidup tidak hanya sekedar dapat memenuhi kebutuhan hidup secara melimpah ruah di dunia, tetapi juga dapat memenuhi ketentraman jiwa sebagai bekal di akhirat nanti.

Ekonomi Syariah merupakan ilmu pengetahuan sosial yang mempelajari masalah-masalah ekonomi rakyat yang dilhami oleh nilai-nilai Islam. Ekonomi syariah atau sistim ekonomi koperasi berbeda dari kapitalisme, sosialisme, maupun negara kesejahteraan (Welfare State). Berbeda dari kapitalisme karena Islam menentang eksploitasi oleh pemilik modal terhadap buruh yang miskin, dan melarang penumpukan kekayaan. Selain itu, ekonomi dalam kaca mata Islam merupakan tuntutan kehidupan sekaligus anjuran yang memiliki dimensi ibadah. ${ }^{18}$

Perbedaan sistem ekonomi syariah dengan sistem ekonomi biasa, yaitu sistem ekonomi syariah dalam memperoleh keuntungan, sistem ini menggunakan cara sistem bagi hasil berbeda dengan sistem ekonomi liberal maupun sosial yang cenderung memperoleh keuntungan sebesarbesarnya tanpa melihat aspek dari konsumennya.

Tujuan dari perekonomian syariah ini adalah mensejahterakan seluruh masyarakat luas, memberikan rasa

\footnotetext{
18 "Ekonomi Syariah," Wikipedia, n.d., http://id.wikipedia.org/wiki/Ekonomi_syariah.
} 
adil, tentram, kebersamaan serta kekeluargaan serta mampu memberikan kesempatan seluas-luasnya kepada setiap pelaku usaha. ${ }^{19}$

Kegiatan ekonomi harus sesuai dengan hukum syara'. Artinya, ada yang boleh dilakukan dan ada yang tidak boleh dilakukan atau dengan kata lain harus ada etika. Kegiatan ekonomi dan kegiatan-kegiatan lainnya yang bertujuan untuk kehidupan di dunia maupun di akhirat adalah merupakan ibadah kepada Allah SWT.

Dalam Islam, harta pada hakikatnya adalah milik Allah, dan harta yang dimiliki oleh manusia sesungguhnya merupakan pemberian Allah, oleh karenanya harus dimanfaatkan sesuai dengan perintah Allah. Orientasi kehidupan manusia menyangkut hakikat manusia, makna hidup, hak milik, tujuan penggunaan sumberdaya, hubungan antara manusia dan lingkungan, harus didasarkan pada Alquran dan Hadist.

Menyangkut sistem ekonomi menurut Islam ada tiga prinsip dasar yaitu Tawhid, Khilafah, dan 'Adalah. Prinsip Tawhid menjadi landasan utama bagi setiap umat Muslim dalam menjalankan aktivitasnya termasuk aktivitas ekonomi. Prinsip ini merefleksikan bahwa penguasa dan pemilik tunggal atas jagad raya ini adalah Allah SWT. Prinsip Tawhid ini pula yang mendasari pemikiran kehidupan Islam yaitu Khilafah (Khalifah) dan 'Adalah (keadilan). ${ }^{20}$

Dalam hal pemilikan sumberdaya atau faktor produksi, Sistem Ekonomi Syariah memberikan kebebasan yang tinggi untuk berusaha dan memiliki sumberdaya yang ada yang berorientasi sosial dengan memberikan selft interest yang lebih panjang dan luas. Namun perlu diingat bahwa, segala sesuatu yang diperoleh merupakan pemberian Allah, karenanya harus digunakan sesuai dengan petunjuk Allah dan dikeluarkan zakat-nya dan sadaqah yang ditujukan bagi Muslim yang belum

${ }^{19}$ Ibid.

20 Buchari Alma, "Ekonomi Syariah," August 8, 2009, http://ekonomisyariah.blog.gunadarma.ac.id/. 
berhasil sebagai implementasi dari rasa sosial yang tinggi. Selain itu, negara dan juga pemerintah berperan untuk menjaga keseimbangan yang dinamis untuk merealisasikan kesejahteraan masyarakat. Jadi, dalam Sistem Ekonomi Syariah, ada landasan etika dan moral dalam melaksanakan semua kegiatan termasuk kegiatan ekonomi, selain harus adanya keseimbangan antara peran pemerintah, swasta, kepentingan dunia dan kepentingan akhirat dalam aktivitas ekonomi yang dilakukan.

\section{Pertumbuhan Ekonomi Islam di Indonesia}

Pertumbuhan ekonomi adalah perkembangan GNP yang terjadi dalam suatu masyarakat yang diikuti oleh perombakan dan modernisasi struktur ekonomi. Pertumbuhan ekonomi adalah kenaikan keluaran total suatu perekonomian sebagai kenaikan GNP. Pertumbuhan ekonomi yang stabil sangat diharapkan oleh Negara yang sedang membangun karena dapat mengatasi masalah kemiskinan, pengangguran, buta huruf, meningkatkan kesejahteraan masyarakat dam memberi perhatian lebih di bidang pendidikan dan kesehatan. Menurut Adam Smith, perkembangan ekonomi memerlukan adanya spesialisasi atau pembagian kerja agar produktivitas tenaga kerja meningkat. ${ }^{21}$

Pertumbuhan ekonomi dalam ekonomi modern adalah perkembangan dalam perekonomian yang menyebabkan barang dan jasa yang diproduksikan dalam masyarakat meningkat yang selanjutnya diiringi dengan peningkatan kemakmuran masyarakat. Dalam kegiatan ekonomi yang sebenarnya, pertumbuhan ekonomi berarti perkembangan ekonomi fiskal yang terjadi di suatu negara seperti pertambahan jumlah dan produksi barang industri, infra struktur, pertambahan jumlah sekolah, pertambahan produksi kegiatan-kegiatan ekonomi yang sudah ada dan beberapa perkembangan lainnya. Dalam analisis makro ekonomi, tingkat

21 Masriah and Mujahid, Pembangunan Ekonomi Berwawasan Lingkungan (Malang: UM Press, 2011), 23. 
pertumbuhan ekonomi yang dicapai suatu negara diukur dengan perkembangan pendapatan nasional riil yang dicapai oleh suatu negara yaitu Produk Nasional Bruto (PNB) atau Produk Domestik Bruto. ${ }^{22}$

Ekonomi Islam pada dasarnya memandang bahwa pertumbuhan ekonomi adalah bagian dari pembangunan ekonomi. ${ }^{23}$ Pertumbuhan ekonomi didefenisikan dengan $a$ suistained growth of a right kind of output which can contribute to human welfare (Pertumbuhan terus-menerus dari faktor produksi secara benar yang mampu memberikan konstribusi bagi kesejahteraan manusia). ${ }^{24}$

Pertumbuhan ekonomi Islam memiliki dasar-dasar filosofis yang berbeda, yaitu: (1) Tauhid rububiyah, yaitu menyatakan dasar-dasar hukum Allah untuk selanjutnya mengatur model pembangunan yang berdasarkan Islam. (2) Keadilan, yaitu pembangunan ekonomi yang merata (growth with equity), (3) Khilafah, yang menyatakan bahwa manusia adalah wakil Allah di muka bumi untuk memakmurkan bumi dan bertanggung jawab atas pengelolaan sumberdaya yang diamanahkan kepadanya, dan (4) Tazkiyah, yaitu mensucikan manusia dalam hubungannya dengan Allah, sesamanya dan alam lingkungan, masyarakat dan negara.

Berdasarkan pengertian tersebut, maka pertumbuhan ekonomi menurut Islam merupakan hal yang sarat nilai. Suatu peningkatan yang dialami oleh faktor produksi tidak dianggap sebagai pertumbuhan ekonomi jika produksi tersebut misalnya memasukkan barang-barang yang terbukti memberikan efek buruk dan membahayakan manusia. Sedangkan istilah pembangunan ekonomi yang dimaksudkan ekonomi Islam adalah the process of allaviating poverty and provision of ease, comfort and decency in life (Proses untuk mengurangi

22 Sadono Sukirno, Pengantar Teori Makro Ekonomi (Jakarta: Raja Grafindo Persada, 1999), 413-14.

23 Abul Hasan M. Sadeq and Aidit Ghazali, Readings in Islamic Economic Thought (Malaysia: Loqman, 1992).

24 Abul Hasan Muhammad Sadeq, Economic Growth in an Islamic Economy (Malaysia: International Islamic University Press, 1987), 55. 
kemiskinan serta menciptakan ketentraman, kenyamanan dan tata susila dalam kehidupan) ${ }^{25}$

Dalam pengertian ini, maka pembangunan ekonomi menurut Islam bersifat multi dimensi yang mencakup aspek kuantitatif dan kualitatif. Tujuannya bukan semata-mata kesejahteraan material di dunia, tetapi juga kesejahteraan akhirat. Keduanya menurut Islam menyatu secara integral.

Pertumbuhan dan pembangunan dalam ekonomi Islam ditekankan pada perhatian yang sangat serius pada pengembangan sumberdaya manusia sekaligus pemberdayaan alam untuk meningkatkan harkat dan martabat manusia. Ini tidak hanya diwujudkan dalam keberhasilan pemenuhan kebutuhan material saja, namun juga kebutuhan dan persiapan menyongsong kehidupan akhirat.

Adapun prinsip pertumbuhan ekonomi Islam antara lain: (a) Pembangunan ekonomi dalam Islam bersifat komprehensif dan mengandung unsur spiritual, moral, dan material. (b) Fokus utama pembangunan adalah manusia dengan lingkungan kulturalnya. (c) Pembangunan ekonomi adalah aktivitas multidimensional sehingga semua usaha harus diserahkan pada keseimbangan berbagai faktor dan tidak menimbulkan ketimpangan dan (d) Penekanan utama dalam pembangunan menurut Islam, terletak pada pemanfaatan sumberdaya yang telah diberikan Allah kepada ummat manusia dan lingkungannya semaksimal mungkin.

Ada beberapa faktor yang akan mempengaruhi pertumbuhan ekonomi. Faktor-faktor tersebut adalah : (1) Sumber daya yang dapat dikelola (invistible resources), (2) Sumber daya manusia (human resources), (3) Wirausaha (entrepreneurship), dan (4) Teknologi (technology).

Pertumbuhan sistem ekonomi syariah di Indonesia sendiri belum sebegitu pesat seperti di negara-negara lain, Secara sederhana, pertumbuhan itu dikelompokkan menjadi pertumbuhan industri keuangan syariah dan pertumbuhan ekonomi syariah non keuangan. Industri keuangan syariah

${ }^{25}$ Ibid., 102. 
relatif dapat dilihat dan diukur pertumbuhannya melalui datadata keuangan yang ada, sedangkan yang non keuangan perlu penelitian yang lebih dalam untuk mengetahuinya. ${ }^{26}$

Di sektor perbankan, hingga saat ini sudah ada tiga Bank Umum Syariah (BUS), 21 unit usaha syariah bank konvensional, 528 kantor cabang (termasuk Kantor Cabang Pembantu (KCP), Unit Pelayanan Syariah (UPS), dan Kantor Kas (KK)), dan 105 Bank Pengkreditan Rakyat Syariah (BPRS). Aset perbankan syariah per Maret 2007 lebih dari Rp. 28 triliun dengan jumlah Dana Pihak Ketiga (DPK) hampir mencapai 22 Triliun. Meskipun asset perbankan syariah baru mencapai 1,63 persen dan dana pihak ketiga yang dihimpun baru mencapai 1,64\% dari total asset perbankan nasional (per Februari 2007), namun pertumbuhannya cukup pesat dan menjanjikan. Diproyeksikan, pada tahun 2008, share industri perbankan syariah diharapkan mencapai 5 persen dari total industri perbankan nasional.

Di sektor pasar modal, produk keuangan syariah seperti reksa dana dan obligasi syariah juga terus meningkat. Sekarang ini terdapat 20 reksa dana syariah dengan jumlah dana kelola 638,8 miliar rupiah. Jumlah obligasi syariah sekarang ini mencapai 17 buah dengan nilai emisi mencapai 2,209 triliun rupiah.

Di sektor saham, pada tanggal 3 Juli 2000 BEJ meluncurkan Jakarta Islamic Index (JII). JII yang merupakan indeks harga saham yang berbasis syariah terdiri dari 30 saham emiten yang dianggap telah memenuhi prinsip-prinsip syariah. Data pada akhir Juni 2005 tercatat nilai kapitalisasi pasar sebesar Rp325,90 triliun atau 43\% dari total nilai kapitalisasi pasar di BEJ. Sementara itu, volume perdagangan saham JII sebesar 348,9 juta lembar saham atau 39\% dari total volume perdagangan saham dan nilai perdagangan saham JII

26 "Perkembangan Ekonomi Syariah Di Indonesia Dan Kontribusinya Bagi Pembangunan Nasional," Ekonomiprofetik. Wordpress.Com, March 24, 2009, http://ekonomiprofetik.wordpress.com/2009/03/24/perkembangan-ekonomisyariah-di-indonesia-dan-kontribusinya-bagi-pembangunan-nasional/.

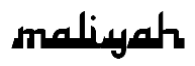


sebesar Rp322,3 miliar atau 42\% dari total nilai perdagangan saham. Peranan pemerintah yang sangat ditunggu-tunggu oleh pelaku keuangan syariah di Indonesia adalah penerbitan Undang-undang Perbankan Syariah dan Undang-undang Surat Berharga Negara Syariah (SBSN).

Di sektor asuransi, hingga Agustus 2006 ini sudah lebih 30 perusahaan yang menawarkan produk asuransi dan reasuransi syariah. Namun, market share asuransi syariah belum baru sekitar 1\% dari pasar asuransi nasional. Di bidang multifinance pun semakin berkembang dengan meningkatnya minat beberapa perusahaan multifinance dengan pembiayaan secara syariah. Angka-angka ini diharapkan semakin meningkat seiiring dengan meningkatnya permintaan dan tingkat imbalan (rate of return) dari masing-masing produk keuangan syariah. ${ }^{27}$

Di sektor mikro, perkembangannya cukup menggembirakan. Lembaga keuangan mikro syariah seperti Baitul Mal wa Tamwil (BMT) terus bertambah, demikian juga dengan aset dan pembiayaan yang disalurkan. Sekarang sedang dikembangkan produk-produk keuangan mikro lain semisal micro-insurance dan mungkin micro-mutual-fund (reksa dana mikro) dilihat dari sisi non keuangan

Industri keuangan syariah adalah salah satu bagian dari bangunan ekonomi syariah. Sama halnya dengan ekonomi konvensional, bangunan ekonomi syariah juga mengenal aspek makro maupun mikro ekonomi. Namun, yang lebih penting dari itu adalah bagaimana masyarakat dapat berperilaku ekonomi secara syariah seperti dalam hal perilaku konsumsi, giving behavior (kedermawanan), dan sebagainya. Perilaku bisnis dari para pengusaha Muslim pun termasuk dalam sasaran gerakan ekonomi syariah di Indonesia. Walau terlihat agak lambat, namun sisi non-keuangan dalam kegiatan ekonomi ini juga semakin berkembang. Hal ini ditandai semakin meningkatnya kesadaran masyarakat terhadap perilaku konsumsi yang Islami, tingkat kedermawanan yang semakin meningkat

27 Ibid. 
ditandai oleh meningkatnya dana zakat, infaq, waqaf, dan sedekah yang berhasil dihimpun oleh badan dan lembaga pengelola dana-dana tersebut.28

Islamic Development Bank (IDB) menyatakan Indonesia merupakan negara dengan pertumbuhan ekonomi syariah tertinggi dibanding negara lain di dunia. Rata-rata pertumbuhan ekonomi syariah global adalah 15-20 persen per tahun, sedangkan pertumbuhan ekonomi syariah Indonesia rata-rata mencapai 35 persen per tahun.

Pertumbuhan ekonomi syariah di Indonesia berbeda dengan negara lain. Di Indonesia, pembiayaan sektor produktif lebih berkembang sementara di Malaysia dan negara-negara lain lebih menyoroti tentang pasar keuangan. Perluasan pasar perbankan syariah akan memperbesar porsi penyaluran kredit yang terbilang masih kecil. Sampai kini perbankan syariah masih menjadikan para pelaku usaha mikro, kecil, dan menengah (UMKM) sebagai target pasarnya. Penyaluran kredit bagi pertanian dapat meningkatkan likuiditas kredit bank syariah. ${ }^{29}$

\section{Peran Kewirausahaan Dalam Pertumbuhan Ekonomi Islam Di Indonesia}

Dalam pertumbuhan ekonomi ada beberapa faktor yang akan mempengaruhi pertumbuhan itu sendiri. Faktor-faktor tersebut adalah:

1. Sumberdaya yang dapat dikelola (invistible resources)

2. Sumberdaya manusia (human resources)

3. Wirausaha (entrepreneurship)

4. Teknologi (technology). ${ }^{30}$

\footnotetext{
28 “Ekonomi Syariah Di Indonesia," Dhogerz.Wordpress.Com, May 15, 2011, http://dhogerz.wordpress.com/2011/05/15/ekonomi-syariah-di-indonesia/.

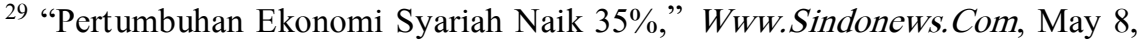
2012, http://www.sindonews.com/read/2012/05/08/452/625578/pertumbuhanekonomi-syariah-naik-35.

${ }^{30}$ Sadeq, Economic Growth in an Islamic Economy, 56.
} 
Wirausaha menjadi salah satu faktor yang mempengaruhi pertumbuhan ekonomi islam dan merupakan kunci dalam proses pertumbuhan ekonomi islam, hal tersebut disebabkan karena, Wirausaha dianggap memiliki fungsi dinamis yang sangat dibutuhkan dalam suatu pertumbuhan ekonomi. Nabi Muhammad Saw, dalam beberapa hadis menekankan pentingnya wirausaha. Dalam hadis riwayat Ahmad beliau bersabda, "Hendaklah kamu berdagang (berbisnis), karena di dalamnya teedapat $90 \%$ pintu rezeki". Dalam hadis yang lain beliau bersabda, "Sesungguhnya sebaik-baik pekerjaan adalah perdagangan (bisnis)".

Wirausaha (entrepreneur) diartikan sebagai seorang inovator dan penggerak pembangunan. Bahkan, seorang wirausaha merupakan katalis yang agresif untuk mempercepat pertumbuhan ekonomi. Harian Kompas edisi Sabtu, 19 April 2009, menurunkan laporan hasil survey terhadap 316 pengusaha dengan judul "Saatnya Dipimpin Oleh Pengusaha". Menurut laporan tersebut, para pengusaha yang disurvei memandang bahwa terkait dengan persoalan ekonomi, sesungguhnya negeri kita sedang mengalami masalah kepempinan. Dengan kata lain, bersangkut-paut dengan upaya keluar dari berbagai persoalan ekonomi, maka sudah seharusnya negeri ini dipimpin oleh seorang presiden yang berasal dari kalangan pengusaha. ${ }^{31}$

Salah satu cara yang paling konstruktif dalam mempercepat pertumbuhan yang berkeadilan adalah dengan membuat masyarakat dan individu untuk mampu semaksimal mungkin mengunakan daya kreasi dan artistiknya secara profesional, produktif dan efisien. ${ }^{32}$

Dalam suatu hadis yang diriwayatkan oleh A'isyah r.a. disebutkan bahwa Nabi Muhammad saw. Bersabda:

"Barang siapa yang menghidupkan tanah yang tidak menjadi milik seseorang, maka ia lebih berhak (atas tanah

${ }^{31}$ Sunarya, Sudaryono, and Saefullah, Kewirausahaan, 20-21.

${ }^{32}$ M. Umer Chapra, Islam Dan Tantangan Ekonomi (Jakarta: Risalah Gusti, 1999), 136. 
itu). "Urwah mengatakan: Umar telah membuat putusan sesuai dengan Hadis ini pada kepemimpinannya.

Dengan demikian, semangat entrepreneurship (kewirausahaaan) dan kewiraswastsaan harus ditumbuhkan dan dibangun dalam jiwa masyarakat, pentingnya pembangunan jiwa wirausaha dalam pembangunan eknonomi di negara-negara muslim yang tergolong miskin. Dalam hal ini ia dikatakan, : Upah buruh bukanlah satu jalan mulus bagi pengurangan kemiskinan, justru wirausahalah yang mempunyai potensi lebih besar dalam meningkatkan basis-basis asset individual daripada yang dimiliki oleh upah kerja. ${ }^{33}$

Menumbuhkan jiwa kewisahausahaan akan mendorong pengembangan usaha kecil secara signifikan. Usaha kecil, khususnya di sektor produksi akan menyerap tenaga kerja yang luas dan jauh lebih besar. industri kecil dan usaha mikro UKM memberikan konstribusi yang besar dalam memberikan lapangan pekerjaan dan pendapatan, mereka mampu menciptakan lapangan kerja bahkan secara tidak langsung mereka berarti mengembangkan pendapatan dan permintaan akan barang dan jasa, peralatan, bahan baku dan ekspor. Mereka adalah industri padat karya yang kurang memerlukan bantuan dana luar (asing), bahkan kadang tidak begitu tergantung kepada kredit pemerintah dibanding insdustri berskala besar.

Saat ini telah muncul kesadaran yang meluas bahwa strategi industrialisasi modern yang berskala besar pada dekade terdahulu secara umum telah gagal memecahkan masalah-masalah keterbelakangan global dan kemiskinan. Industri-industri modern yang berskla besar biasanya kurang dapat menghasilkan keuntungan daripada industri-industri kecil, di samping itu industri besar lebih mahal dalam hal modal dan lebih sedikit menciptakan lapangan pekerjaan. Karena itulah Usaha Mikro (Industri kecil) secara luas dipandang sebagai suatu cara yang efektif untuk meningkatkan konstribusi sektor swasta, baik untuk tujuan-tujuan

\footnotetext{
${ }^{33}$ Muhammad Yunus, The Poor as the Engine of Development, 1988, 31.
} 
pertumbuhan maupun pemerataan bagi negara-negara berkembang.

Peningkatan jumlah wirausaha menyebabkan peningkatan pertumbuhan ekonomi suatu negara. Ada lima alasan yang melatarbelakangi gagasan Schumpeter bahwa wirausaha dapat meningkatkan pertumbuhan ekonomi suatu negara, yakni:

1. Wirausaha yang mengenalkan produk baru dan kualitas baru dari suatu produk,

2. Wirausaha yang mengenalkan metode baru berproduksi yang lebih komersial, baik berdasarkan pengalaman maupun hasil kajian ilmiah dari suatu penelitian,

3. Wirausaha yang membuka pasar baru, baik dalam negeri ataupun di negara yang sebelumnya belum ada pasar,

4. Wirausaha yang menggali sumber pasokan bahan baku baru bagi industri setengah jadi atau industri akhir, dan

5. Wirausaha yang menjalankan organisasi baru dari industri apapun.

Karena kelima hal inilah mengapa wirausaha dapat mendorong peningkatan pertumbuhan ekonomi suatu negara, yaitu karena adanya suatu peningkatan produktivitas.

Karena itulah dengan mengembangkan industri rumah tangga yang sesuai dengan ajaran Islam akan membantu penyediaan lapangan kerja produktif bagi semua anggota masyarakat miskin, dengan demikian akan mengurangi pengangguran dan kemiskinan.

Dari penjelasan di atas dapat dipahami bahwa peran wirausaha dalam menggerakkan pertumbuhan ekonomi merupakan hal yang tak terbantahkan. Kelangkaan wirausaha dapat bisa menyebabkan kurangnya pertumbuhan ekonomi walaupun faktor-faktor lain banyak tersedia. Dalam hal ini pula Islam sangat mendorong pengembangan semangat wirausaha untuk menggalakkan pertumbuhan ekonomi.

Dampak pertumbuhan wirausaha terhadap perekonomian sangat besar, baik ekonomi syariah maupun ekonomi pada umumnya. Perbankan syariah akan menjadi semakin ideal dalam menjalankan fungsi intermediasinya. Penyaluran kredit 
akan berjalan maksimal. Wirausaha juga akan membantu menggerakkan roda perekonomian lewat pembukaan lapangan kerja.

Wirausaha juga terkait dengan penyelenggaraan ibadah lainnya yaitu jika wirausaha dilakukan pada sektor-sektor yang syar'i. Misalnya, usaha biro perjalanan haji dan umroh, akan membantu masyarakat untuk menjalankan ibadah haji atau umroh. Begitu juga pembangunan masjid, sangat membutuhkan keberadaan wirausaha seperti untuk pengadaan bahan-bahan bangunan.

Berwirausaha sesuai dengan ekonomi Islam/syariah. Ekonomi Islam bukan hanya perbankan, asuransi dan pasar modal. Ekonomi Islam juga mencakup persoalan pembangunan dan pertumbuhan ekonomi, dan untuk itu dibutuhkan wirausaha.

Dengan mendorong pertumbuhan ekonomi, wirausaha mempengaruhi seluruh perekonomian, khususnya pengaruhnya pada pasar tenaga kerja. Pertumbuhan ekonomi yang meningkat sangat mungkin akan meningkatkan peluang kesempatan berusaha, namun disisi lain akan mengarah pada tekanan inflasi yang berpengaruh langsung pada upah tenaga kerja. Padahal kenaikan upah tenaga kerja tidak bisa selalu diturunkan dari ketidakseimbangan pada pasar tenaga kerja pasar. ${ }^{34}$

Menteri Koperasi dan UKM (2009-2014), Syarifuddin Hasan, pernah menyatakan harapnnya agar para calon wirausaha dan semua wirausaha yang telah tumbuh dan berkembang saat ini bisa memanfaatkan proyek pembangunan pemerintah dalam mengembangkan usahanya. Keberadaan program Master Plan Percepatan Pembangunan Ekonomi Indonesia (MP3EI), misalnya, menjadi peluang nyata yang bisa dimanfaatkan oleh semua calon wirausaha. Jika MP3EI

\footnotetext{
34 "Mendorong Pertumbuhan Ekonomi Melalui Peningkatan Jumlah Wirausaha Sebuah Kerangka Penelitian," Http://Burhan.Staff.Ipb.Ac.Id, January 24, 2012, http://burhan.staff.ipb.ac.id/2012/01/24/mendorong-pertumbuhan-ekonomimelalui-peningkatan-jumlah-wirausaha-sebuah-kerangka-penelitian/.
} 
dijadikan peluang usaha yang baik oleh para wirausaha, pada tahun 2025, Indonesia bisa masuk 12 negara ekonomi besar dunia dan menjadi delapan negara ekonomi terbesar dunia pada $2045 .{ }^{35}$

Konsep syariah yang diterapkan di bank-bank sudah membuktikan, bagaimana penyaluran pembiayaan di bank syariah selalu berpihak pada sektor riil, dengan angka finance to deposit ratio yang relatif tinggi. Kehadiran bank syariah terbukti bisa diarahkan untuk mendorong tumbuhnya sektor riil, usaha kecil dan menengah yang selama ini menjadi primadona dan tulang punggung di masa krisis.

Berdasarkan data Otoritas Jasa Keuangan (OJK) menunjukkan bahwa per Desember 2014 kinerja lembaga pembiayaan syariah di Indonesia terus mengalami perkembangan yang positif. Pada tahun 2010 total aset lembaga pembiayaan syariah yang terdiri atas bank umum syariah dan unit usaha syariah mencapai senilai Rp 97,52 triliun. Pada tahun 2014 nilai total aset tersebut bertambah menjadi Rp 272,34 triliun, ini artinya selama periode tahun 2010-2014 rata-rata tumbuh sebesar 33,5 persen. Tren positif juga terjadi pada kemampuan menghimpun dana pihak ketiga (DPK). Pada tahun 2010 nilai total DPK yang berhasil dihimpun lembaga pembiayaan syariah senilai $\mathrm{Rp} 76$ triliun dan pada tahun 2014 bertambah menjadi Rp 217,8 triliun. ${ }^{36}$

Perbankan syariah hanya salah satu dari sistem perekonomian Islam. Kalau konsep ekonomi syariah ini akan diterapkan, juga harus diperhatikan peranan lembaga keuangan Islami lainnya seperti peranan zakat, serta peranan lembaga dan dunia usaha Islami yang menjalankan kegiatan usahanya dengan berlandaskan etika dan moral. Contohnya, tidak ada mark-up, tidak ada laporan keuangan ganda dan sejenisnya.

\footnotetext{
35 “Http://Koran-Jakarta.Com/Index.Php/Detail/View01/89826," n.d.

${ }^{36}$ Maltuf Fitri, "Peran Dana Pihak Ketiga Dalam Kinerja Lembaga Pembiayaan Syariah Dan Faktor-Faktor Yang Memengaruhinya," Economica: Jurnal Ekonomi Islam 7, no. 1 (2016): 73.
} 
Lembaga keuangan dan perbankan syariah juga tidak sekadar menjadi lembaga yang baik seperti yang dikenal sekarang ini, tapi juga harus bisa berperan sebagai penghubung antara pihak-pihak yang kelebihan dana dengan pihak-pihak yang kekurangan dana. Sehingga intermediasi juga terwujud dalam sistem perekonomian Islam. ${ }^{37}$

Dengan demikian, peran dari kewirausahaan khususnya terhadap sektor UKM sudah tidak diragukan lagi karena kontribusinyalah pertumbuhan ekonomi islam terus mengalami peningkatan. Meskipun demikian kontribusi tersebut tidak hanya berasal dari sektor UKM saja, tetapi juga berasal dari kontribusi sektor-sektor yang lain. Tetapi dengan adanya peningkatan tersebut dapat memberikan suatu motivasi untuk lebih meningkatkan kemampuan berwirausaha karena selain dapat mengurangi angka kemiskinan, berwirausaha dapat juga mengurangi angka pengangguran, dan dapat meningkatkan presentase UKM yang meminta pinjaman pada bank syari'ah, sehingga meningkatkan pertumbuhan ekonomi Islam. ${ }^{38}$

Pertumbuhan ekonomi merupakan sarana untuk mencapai keadilan distributif, sebagian karena mampu menciptakan kesempatan kerja yang lebih banyak daripada yang mungkin bisa diciptakan dalam keadaan ekonomi statis seperti penciptaan lapangan kerja yang harus diimbangi dengan pemberian tingkat upah yang adil berdasarkan hasil perkembangan usaha produktif yang dipegang oleh setiap pengusaha. Pemerintah dalam hal ini berkewajiban untuk memastikan kesempatan kerja yang luas melalui berbagai kegiatan ekonomi yang aktif pada sektor yang mampu menyerap semua lapisan.

\section{Penutup}

Kewirausahaan merupakan semangat, perilaku, dan kemampuan dalam kreatifitas dan berinovasi serta

\footnotetext{
37 "Www.Eramuslim.Com," n.d.

${ }^{38}$ Masriah and Mujahid, Pembangunan Ekonomi Berwawasan Lingkungan, 27.
} 
memberikan tanggapan yang positif terdapat peluang memperoleh keuntungan untuk diri sendiri dan pelayanan yang lebih baik terhadap masyarakat, dengan selalu berusaha mencari dan melayani masyarakat lebih banyak dan lebih baik, serta menciptakan dan menyediakan produk yang lebih bermanfaat dan menerapkan cara kerja yang efisien, melalui keberanian mengambil resiko, kreatifitas, dan inovasi, serta kemampuan manajemen.

Wirausaha menjadi salah satu faktor yang mempengaruhi pertumbuhan ekonomi islam dan merupakan kunci dalam proses pertumbuhan ekonomi islam, hal tersebut disebabkan karena, wirausaha dianggap memiliki fungsi dinamis yang sangat dibutuhkan dalam suatu pertumbuhan ekonomi. Nabi Muhammad Saw, dalam beberapa hadis menekankan pentingnya wirausaha. Dalam hadis riwayat Ahmad beliau bersabda:

"Hendaklah kamu berdagang (berbisnis), karena di dalamnya terdapat $90 \%$ pintu rezeki".

Dalam hadis yang lain beliau bersabda:

"Sesungguhnya sebaik-baik pekerjaan adalah perdagangan (bisnis)".

Peran dari kewirausahaan khususnya terhadap sektor UKM sudah tidak diragukan lagi karena kontribusinyalah pertumbuhan ekonomi islam terus mengalami peningkatan. Meskipun demikian kontribusi tersebut tidak hanya berasal dari sektor UKM saja, tetapi juga berasal dari kontribusi sektorsektor yang lain. Tetapi dengan adanya peningkatan tersebut dapat memberikan suatu motivasi untuk lebih meningkatkan kemampuan berwirausaha karena selain dapat mengurangi angka kemiskinan, berwirausaha dapat juga mengurangi angka pengangguran, dan dapat meningkatkan presentase UKM yang meminta pinjaman pada bank syari'ah, sehingga meningkatkan pertumbuhan ekonomi Islam

\section{Daftar Pustaka}

Abdullah, M. Ma'ruf. Wirausaha Berbasis Syariah. Banjarmasin: Antasari Press, 2011. 
Alhadihaq, Muhammad Yusuf. "Studi Dampak Pembelajaran Program Literasi Orang Dewasa Dalam Membentuk Perilaku Berwirausaha (Studi Pada Kelompok Belajar Usaha Konveksi Di PKBM Muthia Harapan Mandiri Kecamatan Cicalengka Kabupaten Bandung)." Damar Jayagiri 1 , no. $\quad$ VII (n.d.). https://jurnal.pauddikmasjabar.my.id/index.php/damar/ article/view/11.

Alma, Buchari. "Ekonomi Syariah," August 8, 2009. http://ekonomisyariah.blog.gunadarma.ac.id/.

Chapra, M. Umer. Islam Dan Tantangan Ekonomi. Jakarta: Risalah Gusti, 1999.

"Ekonomi Syariah." Wikipedia, n.d. http://id.wikipedia.org/wiki/Ekonomi_syariah.

"Ekonomi Syariah Di Indonesia." Dhogerz.Wordpress.Com, May 15 , 2011.

http://dhogerz.wordpress.com/2011/05/15/ekonomisyariah-di-indonesia/.

Fitri, Maltuf. "Peran Dana Pihak Ketiga Dalam Kinerja Lembaga Pembiayaan Syariah Dan Faktor-Faktor Yang Memengaruhinya." Economica: Jurnal Ekonomi Islam 7, no. 1 (2016): 73-95.

"Http://Koran-Jakarta.Com/Index.Php/Detail/View01/89826," n.d.

"Islam Dan Mental Kewirausahaan," 2009. http://insaniaku.files.wordpress.com/2009/03/4-islamdan-mental-kewirausahaan-subur.pdf.

Malinda, Maya. "Faktor-Faktor Yang Mempengaruhi Seseorang Berwirausaha (Sebuah Kajian Literatur)." Jurnal Manajemen Maranatha 1, no. Mei (2002): 105-17. https://media.neliti.com/media/publications/113583-IDfaktor-faktor-yang-mempengaruhi-seseoran.pdf.

Masriah, and Mujahid. Pembangunan Ekonomi Berwawasan Lingkungan. Malang: UM Press, 2011.

"Mendorong Pertumbuhan Ekonomi Melalui Peningkatan Jumlah Wirausaha Sebuah Kerangka Penelitian." Http://Burhan.Staff.Ipb.Ac.Id, January 24, 2012. 
http://burhan.staff.ipb.ac.id/2012/01/24/mendorongpertumbuhan-ekonomi-melalui-peningkatan-jumlahwirausaha-sebuah-kerangka-penelitian/.

Nurvidiana, Rahma, Resi Yanuesti Violita, Ferdian Fatikhin, and Zulfa Yunika. "Proses Kewirausahaan." Makalah, 2013.

"Perkembangan Ekonomi Syariah Di Indonesia Dan Kontribusinya Bagi Pembangunan Nasional." Ekonomiprofetik.Wordpress.Com, March 24, 2009. http://ekonomiprofetik.wordpress.com/2009/03/24/per kembangan-ekonomi-syariah-di-indonesia-dankontribusinya-bagi-pembangunan-nasional/.

"Persentase Penduduk Miskin September 2017 Mencapai 10,12

Persen." Badan Pusat Statistik, September 2017. https://www.bps.go.id/pressrelease/2018/01/02/1413/ persentase-penduduk-miskin-september-2017-mencapai10-12-persen.html.

"Pertumbuhan Ekonomi Syariah Naik 35\%." Www.Sindonews.Com, May 8, 2012. http://www.sindonews.com/read/2012/05/08/452/625 578/pertumbuhan-ekonomi-syariah-naik-35.

Purwanti, Endang. "Pengaruh Karakteristik Wirausaha, Modal Usaha, Strategi Pemasaran Terhadap Perkembangan Umkm Di Desa Dayaan Dan Kalilondo Salatiga." Among Makarti 5, no. 9 (2012): 13-28. https://jurnal.stieama.ac.id/index.php/ama/article/view/ 65/46.

Sadeq, Abul Hasan M., and Aidit Ghazali. Readings in Islamic Economic Thought. Malaysia: Loqman, 1992.

Sadeq, Abul Hasan Muhammad. Economic Growth in an Islamic Economy. Malaysia: International Islamic University Press, 1987.

Sukirno, Sadono. Pengantar Teori Makro Ekonomi. Jakarta: Raja Grafindo Persada, 1999.

Sunarya, PO Abas, Sudaryono, and Asep Saefullah. Kewirausahaan. Yogyakarta: C.V Andi Affset, 2011.

Sunarya, Yunus, and Kartib Bayu. Kewirausahaan Pendekatan Karakteristik Wirausahawan Sukses. Jakarta: Kencana 
Peran Kewirausahaan Dalam Pertumbuhan Ekonomi Islam Di Indonesia

Prenada Media Group, 2010.

"Www.Eramuslim.Com," n.d.

Yunus, Muhammad. The Poor as the Engine of Development, 1988. 